\title{
Debukalisasi dan asimilasi fitur dalam bahasa kerinci: Analisis teori autosegmental
}

\author{
Autosegmental Theory Analysis: Debuccalisation and Assimilation \\ Features in Kerinci Language \\ Nur Farahkhanna Mohd Rusli \\ farahkhanna@fbk.upsi.edu.my \\ Universiti Pendidikan Sultan Idris, Tanjung Malim, Perak, Malaysia
}

DOI: https://doi.org/10.37134/pendeta.vol10.10.2019

\begin{abstract}
ABSTRAK
Makalah ini bertujuan menjelaskan proses debukalisasi dan asimilasi fitur dalam bahasa Kerinci berdasarkan teori fonologi autosegmental (Goldsmith, 1976/1990). Data terdiri daripada sumber sekunder dan primer yang diperoleh melalui kaedah kepustakaan, pemerhatian dan temu bual dengan bantuan perakam, borang soal selidik dan buku catatan. Informan merupakan 10 penutur Kerinci yang tinggal di Kampung Batu 21 Sungai Lui, Hulu Langat, Selangor. Dapatan kajian menunjukkan konsonan /s, p, t, k/ tidak dibenarkan berada di koda disebabkan proses debukalisasi yang merealisasikannya sebagai [h, ?]. Vokal yang mendahului konsonan tersebut pula, iaitu /a, u/ akan direalisasikan sebagai [ $₫, \star, a, o]$ akibat proses asimilasi fitur yang melibatkan penyebaran fitur distingtif yang telah dijelaskan secara berpada berdasarkan geometri fitur model Halle (1992). Umumnya, kajian ini bertujuan menjelaskan sebab perubahan bunyi /as/, /up/, /ut/ dan /uk/ berlaku di rima akhir kata bahasa Kerinci.
\end{abstract}

Kata kunci: bahasa Kerinci; debukalisasi; asimilasi fitur; rima akhir kata; fonologi autosegmental

\section{ABSTRACT}

The aim of this article is to explain the processes of debuccalisation and assimilation features in Kerinci language based on the theory of autosegmental phonology (Goldsmith, 1976;1990). This study merely utilized secondary and primary data which were obtained through library research, observations and interviews with are supported with the help of some research instruments including recorders, questionnaires and notebooks. The informants were selected among 10 native speakers of Kerinci language who live in Kampung Batu 21 Sungai Lui, Hulu Langat, Selangor. The finding indicates that the consonants $/ s, p, t, k /$ at the coda position will undergo the debuccalisation process and surfaced as [h, ?]. Vowels that precedes the consonants, /a, $u$, will be realized as [๑, $ә$, a and o] due to the assimilation features process which involved spreading of distinctive features as successfully explained by features of geometry model from Halle (1992). Generally, this study aims to explain the reasons why /u/, /ut/ and $\mathrm{h} \mathrm{k} /$ sounds change at the final syllable in Kerinci language.

Keywords: Kerinci language; debuccalisation; assimilation features; final syllable rhyme; autosegmental phonology

\section{PENGENALAN}

Di Malaysia, bahasa Kerinci merupakan salah satu bahasa daerah atau bahasa sukuan yang bersifat minoriti (minor language). Minoriti dalam konteks ini bukan dianggap sebagai aborigines yang bermaksud masyarakat mundur, primitif dan tidak membangun seperti yang dikemukakan dalam kajian Harishon Radzi, Fazal Mohamed Mohamed Sultan, Nor Hashimah Jalaluddin dan Zaharani Ahmad 
(2012), sebaliknya minoriti dalam kajian ini bermaksud saiz populasi masyarakat Kerinci di Malaysia lebih kecil berbanding komuniti lain, selain penggunaan bahasa yang terhad dalam kalangan penutur berketurunan Kerinci sahaja. Tambahan pula, bahasa Kerinci bukan bahasa asal masyarakat Semenanjung. Sebaliknya, bahasa Kerinci merupakan salah satu kumpulan keluarga bahasa Nusantara yang berasal dari Kabupaten Kerinci, Provinsi Jambi, Sumatera Barat Indonesia (Rozaimah Rashidin \& Nor Diyana Saupi, 2011).

Menurut Asmah Haji Omar (2005), kewujudan masyarakat Kerinci termasuklah Jawa, Bugis, Minangkabau, Mandailing dan sebagainya di Malaysia berlaku disebabkan kecenderungan merantau dan membuka negeri baharu oleh penduduk dari Kepulauan Indonesia ke kawasan tertentu, terutama dalam lingkungan alam Melayu. Bagi Nelmawarni Bungo dan Nordin Hussin (2011), tradisi penghijrahan suku bangsa Melayu dari kepulauan Melayu ke Tanah Melayu paling pesat berlaku pada abad ke-19 dan ke-20.

Berdasarkan rajah salasilah bahasa yang dikemukakan Nik Safiah, Farid M. Onn, Hashim Musa dan Abdul Hamid Mahmood (2010), didapati bahawa bahasa Kerinci mempunyai hubungan kekeluargaan bukan sahaja dengan bahasa Melayu, malah dengan bahasa Aceh, Minangkabau dan sebagainya, iaitu dari segi hubungan sub keluarga bahasa Sumatera. Untuk keterangan lanjut, rajah 1 berikut menunjukkan peringkat hubungan antara bahasa Kerinci dengan bahasa-bahasa lain dalam salasilah bahasa Austronesia:

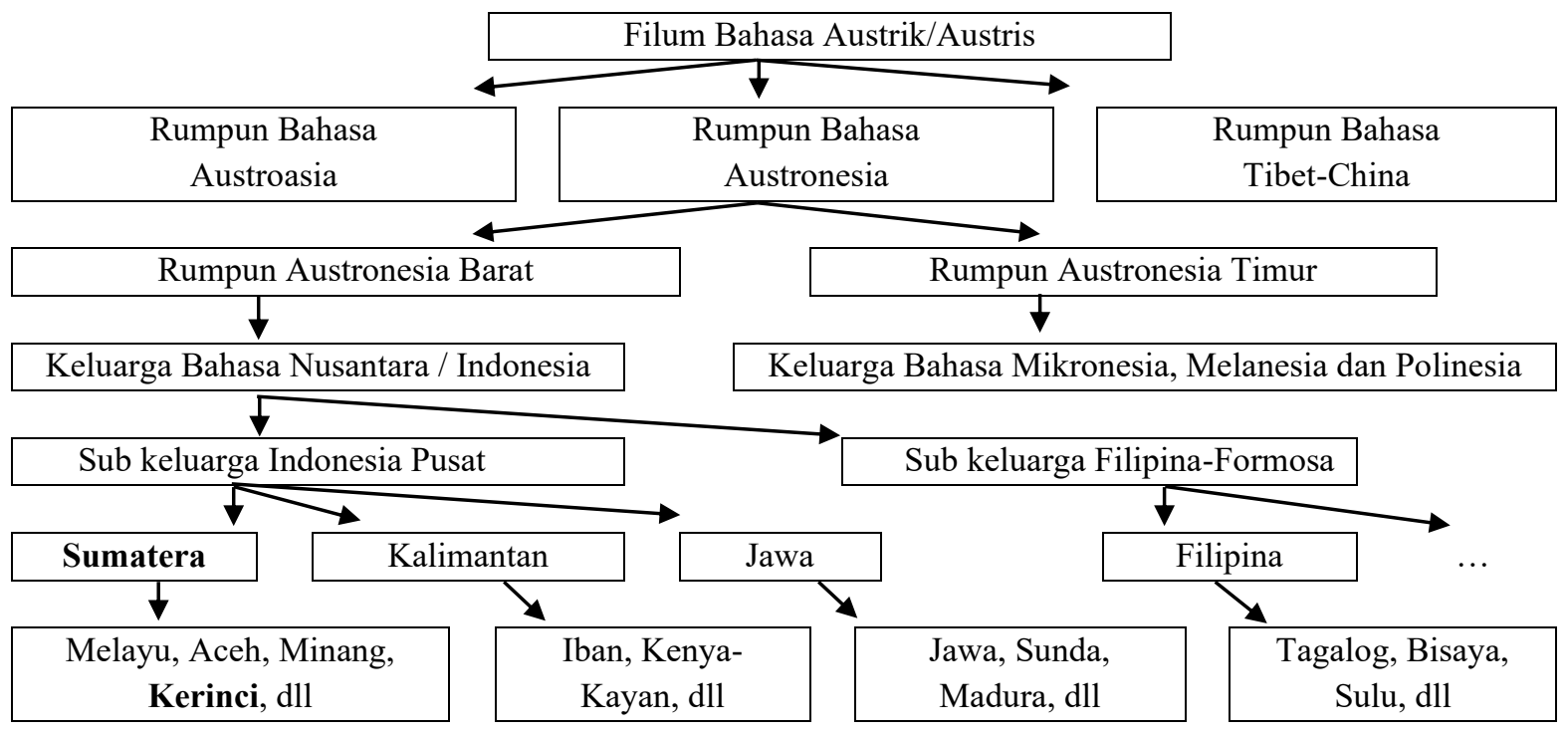

Rajah 1 Salasilah Bahasa Austronesia

(Sumber: Dipetik dan diubah suai daripada Nik Safiah et al., 2010:4-5)

Berdasarkan rajah 1, walaupun bahasa Kerinci, Melayu, Aceh dan Minangkabau tergolong dalam sub keluarga bahasa yang sama, namun setiap bahasa tersebut mempunyai sistem kebahasaan yang berbezabeza dan bukannya dialek kepada satu bahasa yang sama. Oleh itu, sistem fonologi setiap bahasa juga berlainan antara satu sama lain. Dalam bahasa Kerinci sendiri, Jakub Isman (1958) berpendapat bahawa terdapat lebih daripada 80 jenis dialek Kerinci yang berbeza-beza antaranya dialek Semerap, Seleman, Pondok Tinggi, Rawang, Lempur Danau dan sebagainya. Dalam kajian ini, jenis dialek bahasa Kerinci yang dikaji ialah dialek Semerap yang dituturkan oleh masyarakat Kerinci yang tinggal di Kampung Sungai Lui, Hulu Langat, Selangor. "Semerap" merupakan nama salah satu kelurahan (kampung) di Kecamatan Keliling Danau, Kabupaten Kerinci, Provinsi Jambi, Sumatera Barat Indonesia dengan majoriti penduduk di kelurahan tersebut menggunakan bahasa Kerinci dialek Semerap.

Sebelum ini, Rifai (1954) mendakwa bahasa Kerinci merupakan dialek kepada bahasa Minangkabau kerana cara sebutan kata antara kedua-dua bahasa mirip antara satu sama lain. Bagi 
menjelaskan keadaan ini, Prentice dan Usman (1978) dan Adelaar (1992) berpendapat bahawa bukan sahaja bahasa Minangkabau, malah bahasa Melayu-Jambi dan bahasa Melayu Tengah turut mempunyai kaitan dengan bahasa Kerinci. Hal ini diakui oleh McKinnon (2011) dan Ernanda (2011 \& 2015) yang menjelaskan bahawa kaitan tersebut berlaku disebabkan kedudukan Kabupaten Kerinci, Minangkabau dan Jambi yang bersempadan antara satu sama lain.

Kaitan antara bahasa Kerinci dan bahasa Minangkabau berlaku disebabkan kedudukan Kabupaten Kerinci yang menjadi daerah pertemuan antara masyarakat Minangkabau, Melayu-Jambi dan MelayuBengkulu (Amir Hakim Usman, 1983). Faktor tersebut telah menyebabkan berlakunya proses migrasi masyarakat Minangkabau ke Kerinci dan keadaan ini telah menyebabkan masyarakat Kerinci perlu berinteraksi dengan masyarakat Minangkabau untuk berkomunikasi. Kemahiran berbahasa dalam bahasa lain dalam kalangan penutur Kerinci ini secara tidak langsung akan memberi kesan kepada bahasa ibunda mereka (Corella Anak Stephen, Chemaline Anak Osup dan Siti Saniah Abu Bakar, 2017). Hal ini secara tidak langsung menjelaskan rasional sebutan kata dalam kedua-dua bahasa mirip antara satu sama lain.

Seperti yang dijelaskan dalam kajian Rohaidah Haron, Ab. Razak Ab. Karim \& Indirawati Zahid (2018), keadaan ini boleh dianggap sebagai fenomena pertembungan bahasa yang berlaku antara satu bahasa dengan bahasa lain. Para pengkaji ini turut mengemukakan pendapat Brown \& Miller (2013) yang menjelaskan bahawa pertembungan bahasa akan berlaku apabila penutur daripada bahasa berbeza berhubung secara rapat dalam kehidupan seharian. Keadaan ini akan mengakibatkan proses peminjaman kosa kata, fitur fonetik dan struktur gramatikal antara bahasa-bahasa tersebut.

Walaupun keadaan ini berlaku, namun bahasa Kerinci dan bahasa Minangkabau masih merupakan dua sistem bahasa yang berbeza-beza. Perbezaan ini telah dibuktikan melalui kajian yang dilakukan oleh Prentice \& Usman (1978), Voorhoeve (1970), Rozaimah Rashidin \& Nor Diyana Saupi (2011), Amir Hakim Usman (1988), Asmah et al. (2013) dan Nandra (1999) yang menjelaskan cara sebutan kata antara kedua-dua bahasa berbeza-beza seperti yang ditunjukkan dalam jadual 1 berikut:

Jadual 1 Perbezaan data antara bahasa Kerinci dan bahasa Minangkabau

\begin{tabular}{|c|c|c|c|c|}
\hline \multirow[b]{2}{*}{ Bentuk ejaan } & \multicolumn{2}{|c|}{ Bahasa Kerinci } & \multicolumn{2}{|c|}{ Bahasa Minangkabau } \\
\hline & $\begin{array}{c}\text { Rozaimah \& Nor } \\
\text { Diyana (2011) }\end{array}$ & $\begin{array}{c}\text { Amir Hakim Usman } \\
(1988)\end{array}$ & $\begin{array}{l}\text { Asmah et al. } \\
(2013)\end{array}$ & $\begin{array}{l}\text { Nandra } \\
(1999)\end{array}$ \\
\hline 'dagu' & [da.gu] & [da.geu?] & [da.gu.wa?] & [da.gua] \\
\hline 'pipi' & [pi.pi] & [pi.paj] & [pi.pi?] & [pi.pi.ja?] \\
\hline 'rambut' & [am.bu?] & [am.bau?] & [yam.bui?] & [ram.buj?] \\
\hline 'satu' & [sa.tu] & [sa.tau] & [tyi.๑?] & [sa.tua] \\
\hline
\end{tabular}

\section{PENYATAAN MASALAH}

Kajian Mohd Isa Farhy Yassin (1971), Reijn (2001), Rozaimah Rashidin dan Nor Diyana Saupi (2011), McKinnon (2011), Ernanda (2011), Nova Rina dan Fadlul Rahman (2016), Roasharimah Ibrahim (2009) dan Amir Hakim Usman (1988) menunjukkan berlakunya perubahan bunyi terhadap vokal /a, i, u/, konsonan frikatif $/ \mathrm{s} /$ dan konsonan hentian tak bersuara $/ \mathrm{p}, \mathrm{t}, \mathrm{k} /$ yang berada di rima akhir kata. Namun, hasil kajian oleh Kozok (2012) dan Voorhoeve (1970) mengekalkan bunyi vokal atau konsonan /s/ yang berada di rima akhir kata contohnya seperti kata 'digalas', 'batas', 'keris' dan 'menghunus' yang dieja sebagai digalas, batas, karris dan mangoenoes.

Bagi konsonan /p, t, k/ di koda kata, terdapat kekeliruan apabila kajian Roasharimah Ibrahim (2009) menjelaskan hanya vokal yang mendahului konsonan tersebut sahaja yang berubah, manakala konsonan dikekalkan sebagai [p, t, k]. Hal ini tidak dapat menghasilkan justifikasi yang berpada kerana dalam bahasa Kerinci, didapati bahawa vokal /u/ dan konsonan /p, t, k/ di rima akhir kata akan mengalami perubahan bunyi. Hal ini berbeza dengan kajian Nova Rina dan Fadlul Rahman (2016), McKinnon (2011) 
dan Amir Hakim Usman (1988) yang menunjukkan perubahan bunyi terhadap segmen vokal /u/ yang diikuti oleh konsonan /p, t, k/ di koda kata.

Walaupun kajian sebelum ini ada menghuraikan tentang perubahan vokal /a, i, u/ dan konsonan /s, p, t, k/ di rima akhir kata, namun analisis yang dilakukan kebanyakannya menggunakan pendekatan fonologi generatif model linear. Namun, berdasarkan pendekatan non-linear atau teori autosegmental, perubahan yang berlaku ditangani akibat proses asimilasi yang melibatkan penyebaran fitur dan bukan berdasarkan perubahan fitur semata-mata seperti yang terdapat dalam analisis linear. Oleh yang demikian, hasil kajian lalu akan dimanfaatkan dan diberi penilaian semula untuk menjelaskan sebab dan bagaimana perubahan vokal /a, i, u/ dan konsonan /s/ dan /p, t, k/ berlaku di rima akhir kata dalam bahasa Kerinci.

\section{TUJUAN DAN OBJEKTIF KAJIAN}

Kajian ini dilakukan untuk menjelaskan proses debukalisasi dan asimilasi fitur yang berlaku terdahap bunyi /as/, /up, ut, uk/ di rima akhir kata dalam bahasa Kerinci. Selaras dengan tujuan tersebut, maka objektif kajian ini adalah untuk menjelaskan proses debukalisasi dan asimilasi fitur yang berlaku di rima akhir kata bahasa Kerinci berdasarkan teori fonologi autosegmental, iaitu dengan menerapkan analisis model geometri fitur oleh Halle (1992).

\section{SOROTAN LITERATUR}

Hasil kajian Voorhoeve (1970) menunjukkan vokal /a, i, u/ serta konsonan /s, p, t, k/ di rima akhir kata tidak mengalami perubahan bunyi seperti kata 'di atas', 'hidup' dan 'surat' dieja sebagai dadatas, hidup dan surat. Hasil kajian oleh Mohd Isa Farhy (1971) pula menunjukkan kata seperti ‘betis' dan 'elok' dieja sebagai [bətiəh] dan [elou?] mengalami perubahan bunyi di rima akhir kata. Namun, bagi konsonan /t/, ia dikekalkan seperti kata 'sakit' dieja sebagai [sakiet]. Dalam hal ini, bahasa Kerinci bukan sahaja tidak membenarkan konsonan $/ \mathrm{s} /$ dan $/ \mathrm{k} /$ di koda kata, malah $/ \mathrm{p} /$ dan $/ \mathrm{t} /$ juga tidak dibenarkan hadir di posisi tersebut kerana ia direalisasikan sebagai [h] atau [?]. Bagi bunyi vokal, perubahan yang berlaku memerlukan penjelasan terperinci kerana sebab vokal tersebut berubah tidak dibincangkan.

Reijn (2001) ada mengemukakan data seperti kata 'tegas', 'waris', 'terus', 'tutup', 'terkentut', 'balik' yang dieja sebagai tegeah, wareih, terauh, tutua' tekentau' dan bali'. Dalam data tersebut, vokal dan konsonan di rima akhir kata menunjukkan perubahan bunyi. Sebagai contoh, vokal /a, i, o/ yang diikuti oleh /s/ diujarkan sebagai -ea, -ei dan -au manakala vokal /o/ yang diikuti oleh /p/ dan /t/ diujarkan sebagai - au. Bagi konsonan $/ \mathrm{s} /$, ia diujarkan sebagai $[\mathrm{h}]$ dan perubahan tersebut dianggap sebagai suatu proses fonologi yang alamiah. Bagi konsonan /p, t, k/, beliau menggunakan simbol (') sebagai output. Timbul kekeliruan dari segi penggunaan simbol fonetik kerana dalam fonologi generatif, konsonan /p, t, k/ di koda diujarkan sebagai hentian glotis dan perlu dilambangkan sebagai [?] dan bukannya (').

Disamping itu, hasil kajian Roasharimah (2009) turut menemukan perubahan bunyi vokal dan perubahan konsonan /s/ kepada [h] di akhir kata seperti kata 'gadis', 'keris', 'kəbas' dan 'ayah' yang ditranskripsikan sebagai /gadeh/, /kərayh/, /kəb h/ dan /ay $₫ /$. Namun, bagi perubahan vokal dan perubahan konsonan yang melibatkan konsonan /p, t, k/, beliau menjelaskan, "Dalam bahasa Kerinchi, pengglotisan dapat berlaku apabila bunyi hentian glotis (?) mengambil alih peranan bunyi / $k /$ dalam lingkungan akhir kata (hlmn. 95)'. Sebagai contoh, kata 'tembak', 'itik', 'elok' dan 'ngantuk' ditranskripsikan sebagai /nimba?/, /it $§$ ?/, /ilo?/ dan/nanto?/. Namun, untuk konsonan/p/ dan/t/, hanya vokal yang mendahuluinya sahaja yang berubah manakala konsonan tidak berubah contohnya kata 'cukup', 'rambut', 'monyet' dan 'sakit' dieja /čukaup/, /ambaut/, /monait/ dan/sakait/. Dalam hal ini, perlu dijelaskan bahawa perubahan konsonan /s/ kepada $[\mathrm{h}]$ dan situasi perubahan bunyi konsonan /p, t, k/ kepada hentian glotis [?] mengalami rumus fonologi yang sama yang dinamakan sebagai debukalisasi. 
Hal ini seperti yang dijelaskan oleh O’Brien (2012) bahawa proses debukalisasi juga boleh berlaku kepada konsonan /p/ dan /t/ di akhir kata.

Dalam fonologi, debukalisasi (debuccalisation) merupakan proses perubahan bunyi terhadap suatu segmen akibat kehilangan daerah artikulasi oral yang dimiliki oleh segmen tersebut. Proses kehilangan daerah artikulasi oral ini akan menyebabkan segmen tersebut direalisasikan sebagai bunyi glotis, iaitu frikatif glotis [h] atau hentian glotis [?] melalui proses nyah hubung fitur daerah daripada segmen asal tersebut. Dalam erti kata yang lain, konsonan /s, p, t, k/ merupakan konsonan yang mempunyai daerah artikulasi oral yang dihubungkan dengan artikulator (alat artikulasi) labial, koronal dan dorsal. Artikulator labial melibatkan pergerakan bibir manakala artikulator koronal dan dorsal melibatkan pergerakan lidah, iaitu hujung lidah (koronal) dan tengah lidah (dorsal) (Rujuk Rajah 2 di bawah).

Namun, apabila proses debukalisasi berlaku, maka konsonan /s, p, t, k/ akan kehilangan daerah artikulasi oral tersebut dan menyebabkannya direalisasikan sebagai bunyi glotis [h] atau [?]. Rasional perealisasiannya kepada konsonan glotis adalah kerana Lambordi (2001) menjelaskan bahawa kedua-dua segmen glotis tersebut merupakan segmen yang bercirikan tanpa daerah. Penjelasan lanjut tentang proses debukalisasi akan dijelaskan secara terperinci dalam bab dapatan dan perbincangan. Oleh yang demikian, jelas bahawa kajian Roasharimah (2009) akan diberi penilaian semula kerana pemerhatian menunjukkan konsonan /s/ yang didahului oleh vokal /u/, serta konsonan /p/ dan /t/ di akhir kata turut direalisasikan sebagai [h] dan [?].

Selain itu, kajian Amir Hakim Usman (1988) turut menunjukkan perubahan bunyi vokal dan konsonan /s/ dan /p, t, k/ contohnya kata 'unggas', 'manis', 'kurus', 'tegap', 'rambut' dan 'tegak' dieja

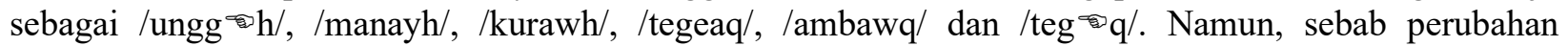
berlaku tidak dibincangkan sebaliknya kajian bertumpu kepada distribusi dan klasifikasi segmen berdasarkan ciri artikulasi yang dikemukakan dalam jadual matriks fitur.

Kajian sebelum ini jelas telah banyak menyumbangkan data tentang proses debukalisasi yang melibatkan konsonan /s/ dan /p, t, k/ di rima akhir kata dalam bahasa Kerinci. Namun, tidak banyak perbincangan yang dilakukan terhadap perubahan vokal yang mendahului konsonan tersebut. Oleh itu, kajian ini akan menilai semula proses fonologi yang melibatkan segmen konsonan dan vokal secara berpada dengan menggunakan teori fonologi autosegmental bertujuan menjawab persoalan mengapa dan bagaimana kedua-dua segmen di lingkungan tersebut berubah.

\section{METODOLOGI}

Kajian ini merupakan suatu kajian tinjauan berbentuk kajian kes. Oleh itu, teknik pensampelan yang digunakan ialah pensampelan bertujuan (purpose sampling), iaitu pemilihan informan dibuat bertujuan menjawab tujuan dan objektif kajian. Seperti yang dijelaskan oleh Othman Talib (2013), pengkaji sudah mempunyai tujuan dan sasaran, maka informan yang dipilih mempunyai kriteria tertentu yang boleh membekalkan maklumat yang diperlukan. Sejajar dengan penyataan ini, maka informan dipilih dalam kalangan 10 orang penutur Kerinci dialek Semerap yang tinggal di Kampung Batu 21 Sungai Lui, Hulu Langat, Selangor. Informan juga dipilih dalam kalangan individu yang telah lama tinggal di Malaysia, iaitu dalam jangka masa 30 tahun ke atas, serta berumur dalam lingkungan 50 tahun ke atas. Pengkhususan tersebut dilakukan bertujuan mendapatkan bahasa Kerinci yang konvensional kerana Nor Hashimah, Norlisafina Sanit, Zaharani Ahmad dan Harishon Mohd. Radzi (2016) berpendapat bahawa warga tua yang berumur 50 tahun ke atas masih cenderung menggunakan dialek asal.

Terdapat tiga kaedah pengumpulan data yang digunakan, iaitu kaedah kepustakaan, pemerhatian dan temu bual. Instrumen yang digunakan terdiri daripada alat perakam, borang soal selidik dan buku catatan. Alat perakam digunakan untuk merakam pertuturan informan. Borang soal selidik digunakan untuk mendapatkan maklumat demografi, pandangan dan pendapat informan tentang situasi penggunaan bahasa Kerinci masa kini. Buku catatan digunakan untuk mencatat semua maklumat yang diberi secara langsung atau tidak langsung sepanjang pemerhatian dijalankan. Data yang diperoleh akan ditranskripsi 
(fonemik, fonetik) dan dianalisis dengan menggunakan teori fonologi generatif model non-linear atau autosegmental (Goldsmith, 1976/1990. Sebelum perbincangan lanjut, berikut dijelaskan terlebih dahulu konsep teori fonologi autosegmental untuk memudahkan pemahaman terhadap analisis yang akan dilakukan.

Berdasarkan teori fonologi generatif model non-linear atau autosegmental, representasi fonologi boleh dijelaskan berdasarkan geometri fitur, iaitu suatu bentuk rajah pohon atau nodus konfigurasi berhierarki yang mempunyai suatu set fitur distingtif. Geometri fitur yang dikemukakan oleh Halle (1992) akan digunakan kerana model tersebut telah mengalami penambahbaikan jika dibandingkan dengan model asal yang diperkenalkan Sagey (1986), dari segi ciri fitur artikulasi, fungsinya dan fungsi nodus artikulator. Untuk keterangan lanjut, rajah 3 berikut menunjukkan model geometri fitur seperti yang dikemukakan oleh Halle (1992):

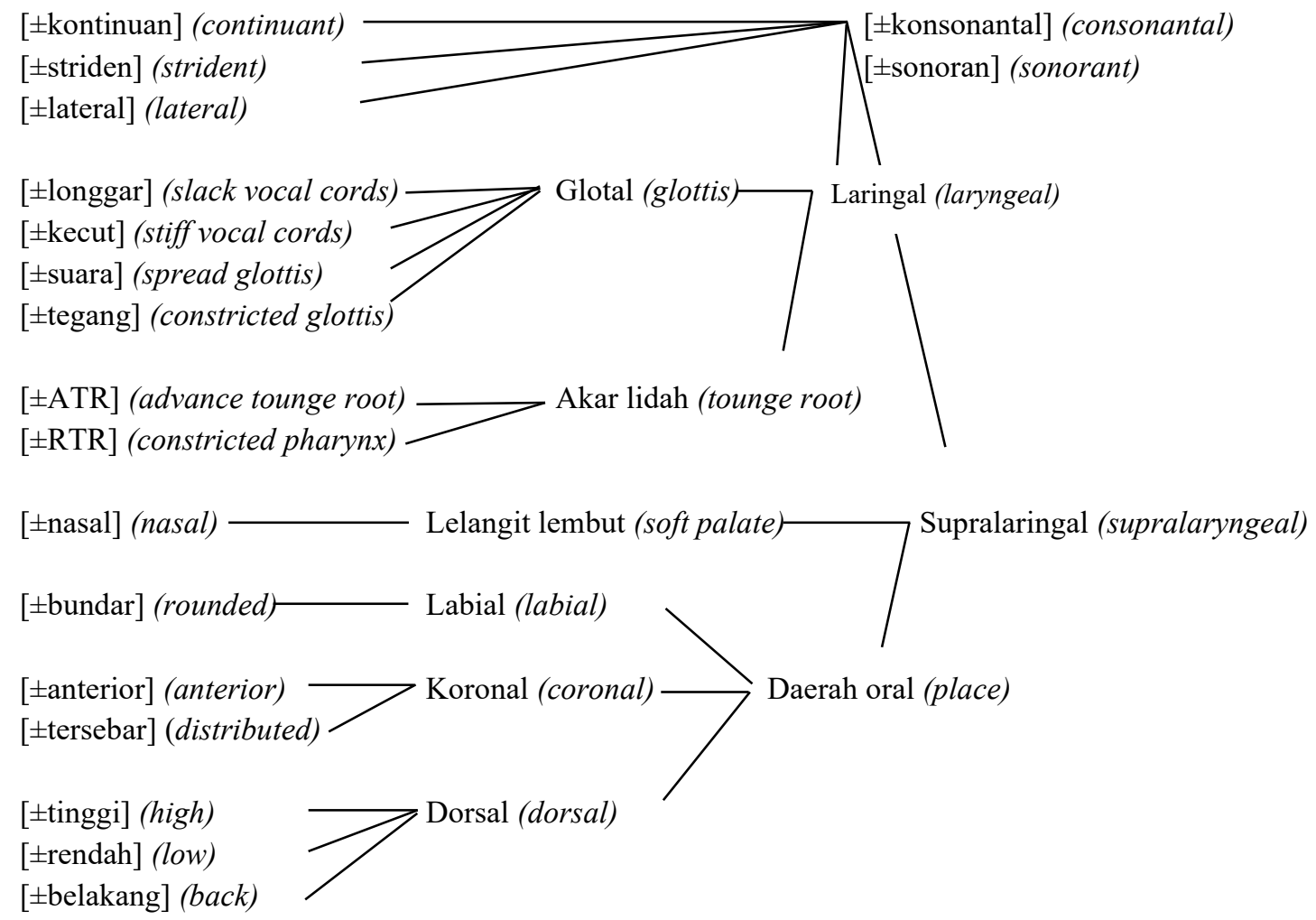

Rajah 2 Model Geometri Fitur Halle (1992)

(Sumber: Halle, 1992: 211)

Bagi Adi Yasran (2005), geometri fitur seperti yang ditunjukkan dalam rajah 2 telah mengambil alih peranan matriks fitur yang digunakan dalam analisis linear. Dengan geometri fitur, representasi suatu proses asimilasi dilihat sebagai penyebaran autosegmental dan bukan perubahan nilai fitur semata-mata seperti yang ditunjukkan matriks fitur. Dalam teori fonologi autosegmental, terdapat tiga proses yang berlaku, iaitu proses hubung (linking), nyah hubung (delinking) dan penyebaran fitur (spreading). Proses hubung bermaksud menghubungkan suatu segmen kepada nodus tertentu dengan menggunakan garis lurus (Zaharani \& Teoh, 2006). Nyah hubung ialah proses yang memutuskan hubungan suatu fitur daripada nodus superordinat lalu menyebabkan ciri tertentu di bawah nodus superordinat tersebut gugur dan hilang daripada segmennya (Trask, 1996). Penyebaran ialah proses yang menerapkan fitur daripada 
suatu segmen kepada segmen lain yang berhampiran dengannya supaya menyerupai segmen tersebut (Schane, 1973). Semua konsep asas proses ini perlu difahami terlebih dahulu untuk memudahkan pemahaman terhadap analisis teori fonologi autosegmental dalam menjelaskan perubahan bunyi yang berlaku dalam bahasa Kerinci.

\section{DAPATAN DAN PERBINCANGAN}

Dalam bahasa Kerinci, ujaran informan menunjukkan bunyi /as/, /up/, /ut/ dan /uk/ di rima akhir kata akan

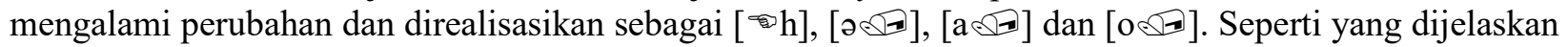
dalam bab metodologi, sumber hasil dapatan ini atau perubahan fonologi ini berlaku diambil berdasarkan kaedah pemerhatian. Dalam hal ini, kaedah pemerhatian turut serta (participant observation) telah digunakan yang menghendaki pengkaji pergi ke kawasan lapangan untuk melihat penggunaan bahasa Kerinci. Melalui kaedah ini, teknik 'pemerhati-sebagai-peserta' telah digunakan yang melibatkan penyertaan pengkaji sama ada secara langsung atau tidak langsung pada sesi pemerhatian yang dijalankan. Walaupun pengkaji berkomunikasi secara langsung dengan informan, namun penglibatan pengkaji dihadkan pada tahap yang minimum untuk mengelakkan gangguan kepada informan yang sedang berkomunikasi kerana dikhuatiri informan akan mengubah pertuturan daripada bahasa Kerinci kepada bahasa Melayu yang sekali gus boleh menjejaskan proses pengumpulan data.

Dalam kajian ini juga, pemerhatian berstruktur telah digunakan, iaitu pengkaji mengenal pasti terlebih dahulu pemboleh ubah yang hendak diperhatikan. Oleh sebab kajian bertujuan menjelaskan proses debukkalisasi dan asimilasi fitur yang melibatkan konsonan dan vokal tertentu, maka pemboleh ubah yang berkaitan yang melibatkan bunyi-bunyi tersebut telah ditetapkan. Kaedah ini membantu pengkaji memerhati, mendengar dan merekod maklumat secara sistematik berdasarkan set pemboleh ubah yang telah dikenal pasti di peringkat awal (Mohd. Majid Konting, 1990). Sepanjang pemerhatian, kaedah rakaman dan catatan telah digunakan untuk merekod maklumat yang berkaitan dengan isu yang dikaji.

Berdasarkan perubahan bunyi /as/, /up/, /ut/ dan /uk/ di rima akhir kata kepada bunyi [ $₫$ ], $[\partial \odot],[a \odot]$ dan $[0 \Theta]$, terdapat dua jenis pola perubahan yang dikenal pasti. Pertama, perubahan yang melibatkan segmen konsonan. Kedua, melibatkan perubahan yang melibatkan segmen vokal. Berikut adalah sebahagian data yang menunjukkan perubahan-perubahan tersebut:

Jadual 2 Data perubahan bunyi /as/, /up/, /ut/ dan /uk/ di rima akhir kata

\begin{tabular}{|c|c|c|}
\hline Bentuk fonemik & Bentuk fonetik & Bentuk ejaan \\
\hline /b $\star \mathrm{kas} /$ & {$[\mathrm{b} \star . \mathrm{k} \circledast \mathrm{h}]$} & 'bekas' \\
\hline /panas/ & [pa. $\tilde{n} \rrbracket \mathrm{h}]$ & 'panas' \\
\hline /saægup/ & {$[\mathrm{sa} . \mathrm{g} \star \Theta]$} & 'sanggup' \\
\hline /rədup/ & {$[\mathrm{ro} . \mathrm{d} \star \Omega]$} & 'redup' \\
\hline /sambut/ & [sam.ba@] & 'sambut' \\
\hline /tgabut/ & {$[$ fa.ba@ $\Theta]$} & 'cabut' \\
\hline /masuk/ & [mã.so@] & 'masuk' \\
\hline /habuk/ & {$[$ a.bo@ $\Theta]$} & 'habuk' \\
\hline
\end{tabular}

Berdasarkan jadual 2, vokal dan konsonan di rima akhir kata mengalami perubahan bunyi apabila direpresentasikan (dikemukakan) di peringkat output. Dari segi konsonan, perubahan berlaku disebabkan syarat koda bahasa Kerinci yang tidak membenarkan segmen daerah, iaitu konsonan frikatif /s/ dan konsonan hentian tak bersuara /p, t, k/ menduduki posisi koda kata. Menurut Ito $\Upsilon$ (1986), kekangan 
yang tidak membenarkan segmen berada di koda ini dikawal oleh syarat koda suku kata (syllable coda condition). Bagi mematuhi kekangan tersebut, maka proses debukalisasi (debuccalisation) akan dilaksanakan.

Seperti yang dijelaskan oleh O' Brien (2012), proses debukalisasi akan menyebabkan suatu segmen kehilangan daerah artikulasi oralnya dan hal ini akan menyebabkan konsonan /s/ dan konsonan $/ \mathrm{p}, \mathrm{t}, \mathrm{k} /$ masing-masing direalisasikan sebagai segmen frikatif glotis [h] dan segmen hentian glotis [@]. Secara autosegmentalnya, formalisasi rumus yang dapat menjelaskan perubahan /s/ kepada [h] dan perubahan /p, t, k/ kepada [@] dikemukakan dalam rumus 1 dan rumus 2 berikut:

1. Nyah hubung fitur daerah /s/

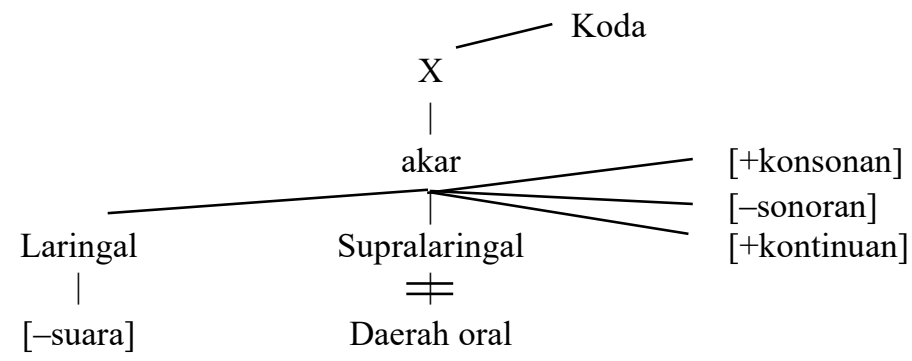

Rumus 1 menunjukkan fitur daerah daripada konsonan /s/ telah dinyahhubungkan daripada nodus akar. Proses ini akan menyebabkan konsonan /s/ kehilangan fitur daerah dan tidak lagi memiliki daerah artikulasi oral. Hal ini akan menyebabkannya hanya dihubungkan dengan nodus laringal. Menurut Lombardi (2001), segmen laringal diwakili oleh segmen [h] dan [?]. Oleh sebab konsonan /s/ berfitur [+kontinuan], maka segmen yang direpresentasikan di peringkat output dalam rumus 1 bertepatan dengan ciri distingtif bagi segmen frikatif glotis [h] yang juga berfitur [+kontinuan].

Bagi Lombardi (2001), fitur laringal yang dimiliki oleh segmen $[\mathrm{h}]$ bercirikan tanpa daerah. Dari segi fonetik, Adi Yasran (2005) menjelaskan segmen [h] merupakan segmen bukan daerah kerana kedudukan lidah semasa penghasilannya tidak berada di titik artikulasi sebaliknya, kedudukan lidah berada dalam keadaan terapung atau tidak menyentuh mana-mana titik artikulasi yang berada di dalam rongga mulut. Walau bagaimanapun, Browman dan Goldstein (1986) berpendapat walaupun segmen [h] tiada fitur daerah, namun masih terdapat gerakan alat artikulasi untuk menghasilkan bunyi vokal yang mendahului atau mengikuti konsonan tersebut.

Bagi Adi Yasran (2005), proses ini tidak dapat ditunjukkan dengan menggunakan jadual matriks fitur seperti yang terdapat dalam analisis linear. Berbeza dengan representasi non-linear atau teori autosegmental, proses ini dapat ditunjukkan melalui interaksi garis penghubung dengan fitur distingtif, serta tingkat nodus yang terdapat di dalam geometri fitur. Berikut pula adalah formalisasi rumus untuk proses debukalisasi yang berlaku terhadap konsonan /p, t, k/:

2. Nyah hubung fitur daerah $/ p, t, k /$

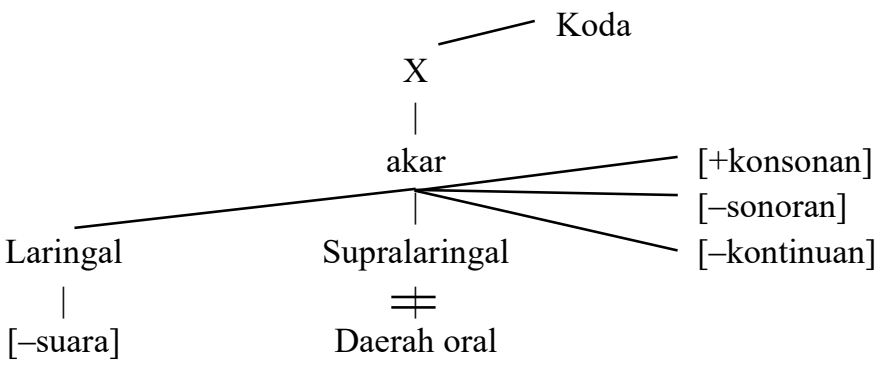


Rumus 2 menunjukkan fitur daerah daripada /p, t, k/ telah dinyahhubungkan daripada nodus akar. Ertinya, fitur [+bundar], [+anterior] dan [+belakang] yang dimiliki oleh konsonan /p, t, k/ yang asalnya dihubungkan dengan fitur kelas utama melalui nodus daerah labial, dorsal dan koronal telah dinyahhubungkan. Nodus laringal pula masih berhubung dengan nodus akar. Keadaan ini akan menyebabkan fitur yang tinggal dalam representasi rumus 2 ialah [-suara] dan [-kontinuan] yang jelas bertepatan dengan ciri distingtif bagi segmen hentian glotis [ $[\pi]$.

Dalam fonologi, konsonan /p, t, k/ tergolong dalam satu kelas alamiah (kelas natural) yang sama kerana ketiga-tiganya merupakan konsonan hentian tak bersuara. Menurut Farid (1984), konsep kelas natural ini penting untuk menunjukkan suatu proses fonologi bertindak terhadap segmen dalam satu kelas natural yang sama dan bukannya bertindak kepada segmen secara individu atau satu per satu. Malah, kelas natural bagi konsonan /p, t, k/ dalam bahasa Kerinci sama dengan kelas natural bagi konsonan /p, t, $\mathrm{k}$ / dalam bahasa Melayu kerana ketiga-tiga konsonan dihasilkan dengan cara hentian (unaspirated), iaitu tiada udara yang mengalir keluar daripada sekatan yang dilakukan di dalam rongga mulut (Shahidi \& Rahim Aman, 2011). Oleh sebab itu, formalisasi rumus 2 merepresentasikan konsonan /p, t, k/ dalam satu representasi fitur yang sama dan bukannya secara berasingan.

Selain konsonan [h] seperti yang dibincangkan sebelum ini, Lombardi (2001), Clements \& Hume (1995) dan Trigo (1988) dalam de Lacy (2002) turut berpendapat bahawa hentian glotis [\&] juga merupakan segmen tanpa daerah. Walaupun [h] dan [@] bercirikan tanpa daerah, namun Teoh (1994) menjelaskan kedua-dua segmen boleh dibezakan dari cara penghasilannya, iaitu melalui fitur [ \pm kontinuan]. Segmen frikatif glotis [h] berfitur [+kontinuan] kerana cara penghasilannya tidak melibatkan penyempitan oral (oral closure) jika dibandingkan dengan hentian glotis [@] yang berfitur [-kontinuan] kerana cara penghasilannya yang melibatkan penyempitan oral.

Tambah Adi Yasran (2012), fakta tentang perealisasian konsonan frikatif $/ \mathrm{s} / \rightarrow[\mathrm{h}]$ dan hentian $/ \mathrm{p}$, $\mathrm{t}, \mathrm{k} / \rightarrow[\Theta]$ ini telah dapat menunjukkan interpretasi abstrak secara relatif tentang fitur kontinuan, iaitu [+kontinuan] membolehkan udara mengalir keluar di dalam rongga mulut tanpa sekatan manakala [-kontinuan] adalah penghentian (stoppage) hembusan udara yang bebas daripada artikulator tertentu seperti bibir, daun lidah (tounge blade), pangkal lidah (tounge dorsum) atau dalam kes laringal, tentunya dengan ketiadaan artikulator (kecuali pita suara).

Dalam bahasa Kerinci, proses debukalisasi yang berlaku terhadap konsonan /s/ dan /p, t, k/ sangat penting untuk menjelaskan perubahan yang berlaku terhadap vokal /a, i, u/ yang mendahului konsonan tersebut di rima akhir kata. Hal ini kerana, perubahan yang berlaku terhadap vokal mempunyai hubung kait dengan proses debukalisasi yang berlaku terhadap segmen konsonan tersebut. Berdasarkan teori fonologi autosegmental, perubahan yang berlaku terhadap segmen vokal dapat dijelaskan akibat asimilasi fitur. Menurut Zaharani (2003 \& 2007), rumus asimilasi dalam analisis non-linear ditafsirkan sebagai proses penyebaran fitur daripada segmen sumber kepada segmen sasaran. Untuk keterangan lanjut, berikut dijelaskan satu persatu tentang proses asimilasi fitur yang dapat menjelaskan perubahan yang berlaku terhadap vokal /a, i, u/ dalam bunyi /as/, /up/, /ut/ dan /uk/ yang direalisasikan sebagai [ , ə, a, o] dalam output $[\varpi \mathrm{h}],[\star \Theta]$, [a@] dan $[\mathrm{o} @]$.

\section{A) PERUBAHAN /as/ KEPADA [}

Berdasarkan ujaran informan, kata yang berakhir dengan bunyi /as/ akan direalisasikan sebagai [ $\mathrm{h}$ ] contohnya kata seperti /bəkas/ dan /panas/ diujarkan sebagai [bə.k h] 'bekas' dan [pa.ñ Berdasarkan teori fonologi autosegmental, perubahan yang berlaku terhadap konsonan $/ \mathrm{s} /$ dapat diformalisasikan dalam rumus yang berikut:

3. Geometrifitur menunjukkan $/ a / \rightarrow[\square]$ 


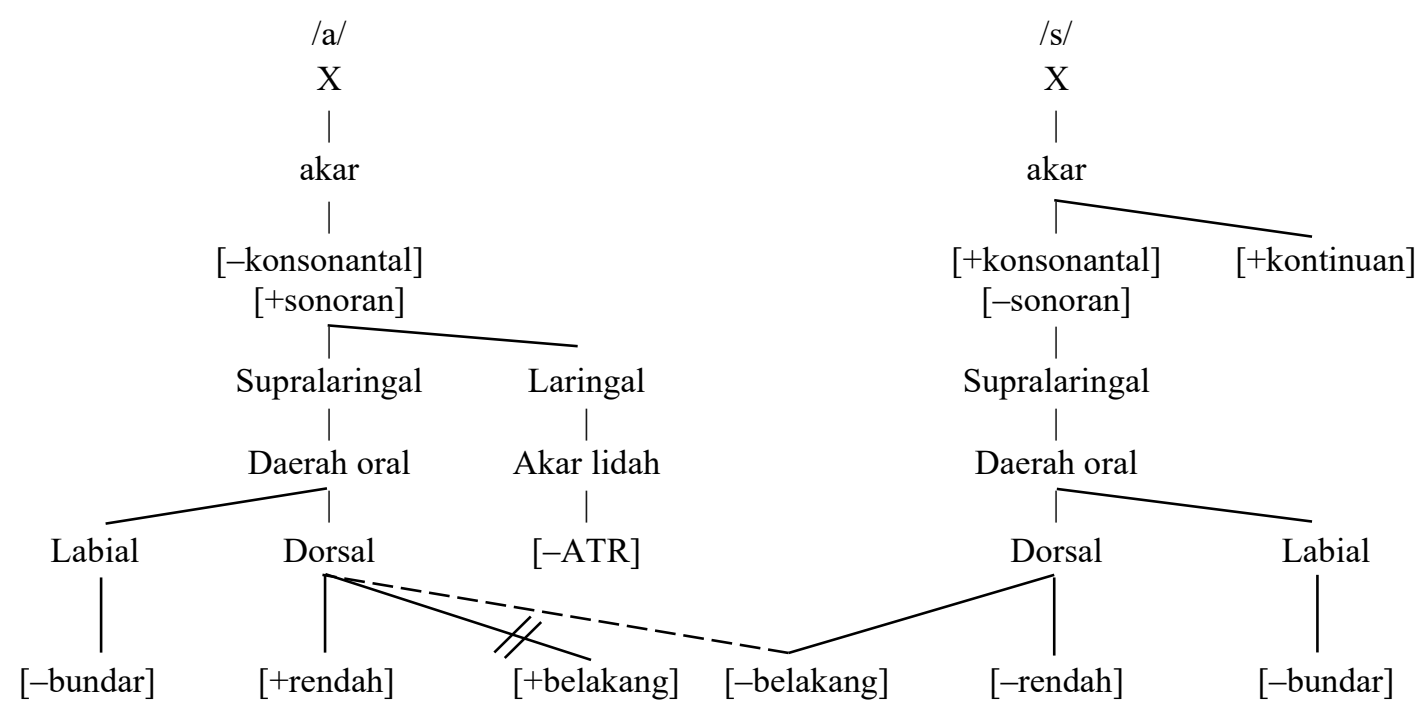

Berdasarkan rumus 3, apabila fitur [+belakang] daripada vokal /a/ telah dinyahhubungkan, maka representasi fonologi segmen vokal tidak lagi mempunyai ciri [+belakang]. Pada masa yang sama, proses asimilasi turut berlaku, iaitu fitur [-belakang] daripada konsonan /s/ yang bersebelahan dengannya disebarkan kepada segmen vokal lalu menyebabkan representasi fonologi segmen vokal kini turut mempunyai fitur [-belakang]. Oleh sebab dalam bahasa Kerinci

hanya vokal /i/, /e/ dan [ ${ }^{\varpi}$ ] yang berfitur [-belakang], maka kombinasi fitur [+rendah], [-bundar], [-ATR] dan [-belakang] dalam representasi fonologi segmen vokal dalam rumus 3 jelas bersamaan dengan ciri distingtif bagi vokal [Ð] dalam sistem fonologi bahasa Kerinci.

Dalam perubahan /as/ kepada [ $\$$ h], penyebaran fitur [-belakang] daripada konsonan /s/ telah mempengaruhi perealisasian vokal /a/ yang berfitur [+belakang] kepada vokal [ ${ }^{\circ}$ ] yang berfitur [-belakang]. Penghasilan vokal [ ${ }^{\circledast}$ ] didorong oleh fitur distingtif yang dimiliki oleh konsonan /s/ yang bersebelahan dengannya dalam kata. Hal ini jelas menunjukkan suatu proses asimilasi yang sebelum ini ditafsirkan sebagai penyebaran fitur daripada segmen sumber kepada segmen sasaran. Proses yang berlaku ini akan menyebabkan suatu segmen menerapkan fitur tertentu daripada segmen berdekatan dengannya supaya menyerupai segmen tersebut (Kenstowicz \& Kisseberth, 1979), dan dalam hal ini, vokal [Ð] dan konsonan /s/ kedua-duanya mempunyai persamaan fitur dari segi [-belakang].

Dari segi motivasi fonetik, urutan segmen dengan fitur yang sama lebih mudah diujarkan. Oleh sebab itu, rumus pendepanan vokal yang merealisasikan /a/ kepada [ ${ }^{\square}$ berlaku kerana bunyi $*$ [ $\mathrm{s}$ ] lebih mudah diujarkan. Seterusnya, data turut menunjukkan perubahan terhadap konsonan /s/ di koda yang direalisasikan sebagai [h]. Seperti yang dijelaskan sebelum ini, bahasa Kerinci mempunyai kekangan yang menghalang konsonan /s/ berada di koda dan kekangan ini dikawal oleh proses debukalisasi. Melalui pelaksanaan proses debukalisasi seperti yang diformalisasikan dalam rumus 1 , konsonan /s/ di koda kata dalam bunyi *[ tersebut, output [ $[\mathrm{h}]$ akan dihasilkan seperti yang direpresentasikan dalam kata $[\mathrm{b} \star . \mathrm{k}$ ॠ] 'bekas' dan [pa.ñ $₫$ h] 'panas'.

Sebelum ini, hasil kajian oleh Adi Yasran Abdul Aziz, Raja Masittah Raja Ariffin, Mohd Sharifudin Yusop dan Nur Farahkhanna Mohd Rusli (2014) ada menjelaskan tentang perubahan /as/ kepada [ ${ }^{\mathrm{h}}$ ] dalam bahasa Kerinci. Namun, kajian yang menggunakan teori fonologi generatif model linear tersebut menjelaskan perubahan yang berlaku dari segi pengaturan rumus, iaitu perubahan /as/ kepada [ $₫$ ] didasari oleh seperangkat rumus yang dilaksanakan secara beraturan dalam satu proses derivasi. Berdasarkan kajian tersebut, rumus yang merealisasikan /a/ kepada [ $₫$ ] perlu dilaksanakan terlebih dahulu untuk menyediakan input yang membenarkan perubahan $/ \mathrm{s} / \mathrm{kepada}[\mathrm{h}]$ berlaku selepasnya. Tambah Adi Yasran et al. (2014), jika aturan tersebut tidak dipatuhi, output yang tidak tepat akan dihasilkan. 
Berbanding dengan analisis model non-linear yang diterapkan dalam kajian ini, fitur distingtif yang direpresentasikan dalam bentuk geometri fitur seperti yang ditunjukkan dalam rumus 1 dan 3 lebih berpada dalam menangani perubahan /as/ kepada [ $\mathrm{h}$ ], iaitu melalui proses debukalisasi dan rumus asimilasi fitur. Hal ini kerana analisis berdasarkan model non-linear telah melalui pelbagai penambahbaikan dan pengemaskinian, terutama dari segi representasi fonologi dan notasi rumus jika dibandingkan dengan model linear. Ertinya, teori ini dapat menangani proses fonologi dengan lebih berpada, bersifat alamiah dan munasabah. Bagi Adi Yasran (2005), dengan menggunakan analisis berdasarkan geometri fitur, representasi suatu proses asimilasi dapat dilihat sebagai penyebaran autosegmental dan bukan perubahan nilai fitur semata-mata seperti yang ditunjukkan matriks fitur dalam analisis linear.

\section{B) PERUBAHAN /up/ KEPADA [a@]}

Dalam bahasa Kerinci, kata yang berakhir dengan bunyi /up/ akan direalisasikan sebagai [ə๔] seperti $\mathrm{kata} /$ saygup/ dan /rədup/ diujarkan sebagai [say.gə@] 'sanggup' dan [rə.də@] 'redup'. Berdasarkan teori autosegmental, perubahan yang berlaku diformalisasikan dalam rumus berikut:

\section{Geometri fitur menunjukkan $/ u / \rightarrow[\partial]$}

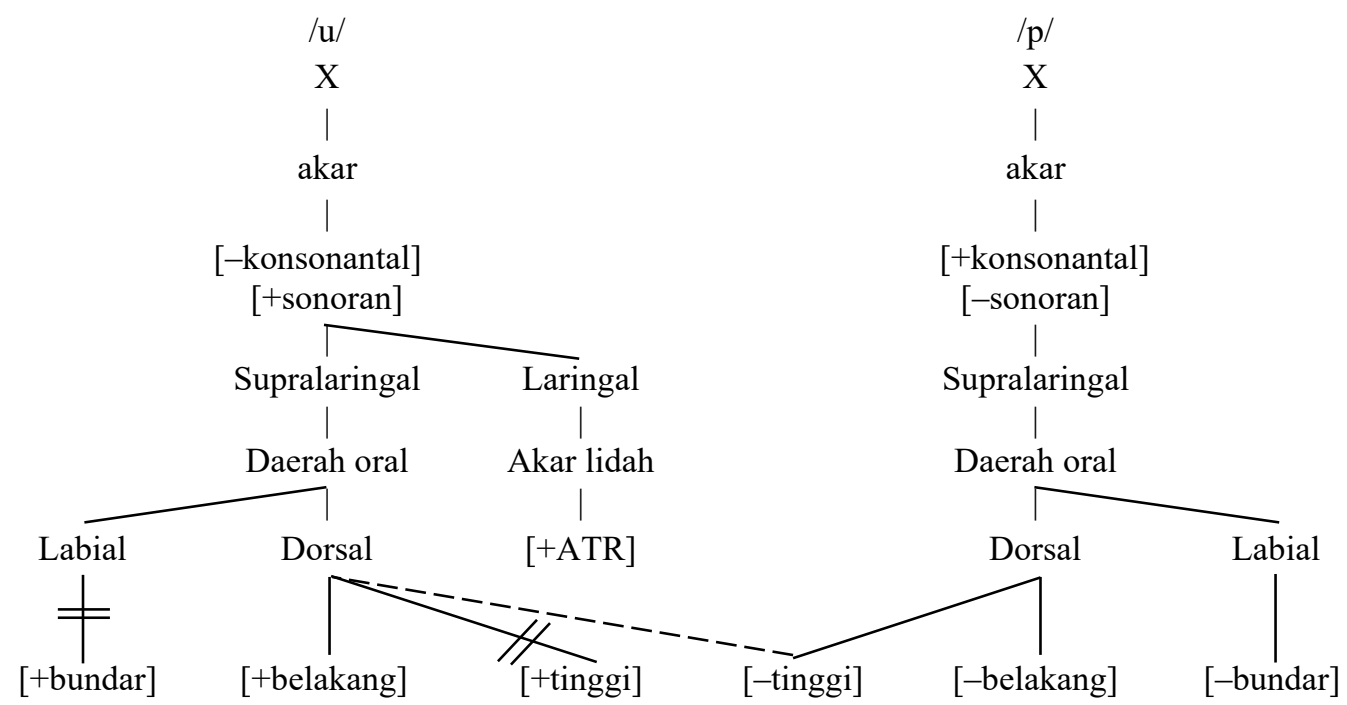

Berdasarkan rumus 4, apabila fitur [+bundar] dan [+tinggi] daripada vokal /u/ dinyahhubungkan, maka representasi fonologi segmen vokal tidak lagi mempunyai kedua-dua ciri distingtif tersebut. Rumus 4 turut menunjukkan suatu proses asimilasi yang melibatkan penyebaran fitur [-tinggi] daripada konsonan /p/ yang mengikuti vokal tersebut. Proses penyebaran yang berlaku akan menyebabkan representasi fonologi segmen vokal kini turut mempunyai fitur [-tinggi]. Berdasarkan perubahan tersebut, kombinasi fitur [-bundar], [+belakang], [-tinggi] dan [+ATR] dalam representasi fonologi segmen vokal dalam rumus 4 jelas bersamaan dengan ciri distingtif yang dimiliki oleh vokal schwa [ə] dalam bahasa Kerinci.

Dalam rumus 4, penyebaran fitur [-tinggi] daripada konsonan $/ \mathrm{p} /$ menjadi faktor yang mempengaruhi perealisasian vokal /u/ yang berfitur [+tinggi] kepada vokal [ə] yang [-tinggi]. Ertinya, vokal /u/ kehilangan titik artikulasinya melalui proses nyah hubung, namun kemudian memperoleh titik artikulasi baharu daripada konsonan /p/ yang bersebelahan dengannya selepas proses asimilasi terlaksana. Hal ini seperti yang dijelaskan oleh Noor Azureen dan Tajul (2013) yang berpendapat bahawa proses penyebaran fitur menunjukkan kecenderungan segmen menguasai segmen bersebelahan dengannya, dengan menyebarkan fitur dan membentuk segmen yang mempunyai identiti yang hampir sama. 
Bagi Halle (1995), proses ini menggambarkan titik artikulasi memiliki gugus fitur yang boleh tersebar semasa penyebaran fitur dan akan menyebabkan perubahan nilai terhadap sesuatu fitur, iaitu sama ada ia berkongsi fitur yang sama dengan segmen sumber atau berubah menjadi segmen lain. Malah, perubahan yang berlaku menunjukkan proses asimilasi yang alamiah kerana [ə] dan /p/ di rima akhir kata keduaduanya berfitur [-tinggi] dan [-bundar] yang jelas mempunyai motivasi fonetik, iaitu dari segi urutan segmen dengan fitur yang sama yang lebih mudah diujarkan jika dibandingkan dengan keadaan yang sebaliknya.

Selain itu, perubahan /u/ kepada [ə] ditangani oleh rumus pelemahan atau reduksi vokal. Dari segi kualiti bunyi, Jones (1972) berpendapat vokal /ə/ merupakan vokal lemah kerana ketegangan otot lidah semasa penghasilannya berada dalam keadaan yang lebih kendur berbanding dengan ketegangan otot lidah ketika menghasilkan bunyi vokal lain. Dari segi fitur pula, Roca dan Johnson (1999) dan Adi Yasran (2005) mengelaskan vokal /ə/ dan /a/ sebagai vokal kendur (lax) manakala vokal lain termasuk /u/ sebagai vokal tegang (tense). Ertinya, vokal/ə/ berfitur [-tegang] manakala /u/ berfitur [+tegang]. Oleh sebab itu, perubahan /u/ kepada [ə] dinamakan sebagai reduksi kerana proses tersebut menunjukkan pelemahan daripada fitur [+tegang] kepada [-tegang].

Seterusnya, data sebelum ini menunjukkan perubahan terhadap konsonan /p/ di koda yang direalisasikan sebagai hentian glotis [@]. Oleh sebab bahasa Kerinci tidak membenarkan konsonan /p/ berada di koda kata disebabkan kekangan syarat koda, maka proses debukalisasi dilaksanakan. Melalui pelaksanaan proses debukalisasi seperti yang diformalisasikan dalam rumus (2), maka konsonan /p/ di koda kata dalam bunyi *[əp] akan direalisasikan sebagai [@]. Di peringkat akhir pelaksanaan proses tersebut, output [ə]] akan dihasilkan seperti yang direpresentasikan dalam kata [san.gə日] 'sanggup' dan [rə.də@]] 'redup'.

Sebelum ini, kajian Nur Farahkhanna et al. (2015) ada menjelaskan tentang perubahan bunyi /up/ kepada [ə๔] dalam bahasa Kerinci. Berdasarkan kajian yang menggunakan analisis model linear tersebut, didapati bahawa perubahan /up/ kepada [ə@] berlaku disebabkan interaksi dua rumus fonologi yang dilaksanakan secara berurutan, iaitu perubahan /u/ kepada [ə] perlu dilaksanakan terlebih dahulu untuk menyediakan input yang tepat yang membenarkan perubahan /p/ kepada [ $₫$ ] beroperasi selepasnya. Malah, kajian tersebut mengandaikan bahawa jika aturan tersebut tidak dipatuhi, maka output yang tidak tepat akan dihasilkan.

Namun, seperti yang diformalisasikan dalam rumus 2 dan 4, fitur distingtif yang direpresentasikan dalam bentuk geometri fitur lebih berpada dalam menangani perubahan /up/ kepada [ə๔], iaitu melalui proses debukalisasi dan rumus asimilasi fitur. Seperti yang dijelaskan sebelum ini, analisis model non-linear telah melalui pelbagai penambahbaikan, terutama dari segi representasi fonologi dan notasi rumus jika dibandingkan dengan model linear. Walaupun tidak bersifat kontemporari, namun teori autosegmental lebih berupaya dalam menangani suatu proses fonologi yang berlaku dalam sesuatu bahasa dengan lebih berpada, bersifat alamiah dan munasabah berbanding dengan teori fonologi model linear. Malah, analisis berdasarkan geometri fitur seperti dalam rumus 2 dan 4 juga menunjukkan bahawa representasi suatu proses asimilasi dapat dilihat sebagai penyebaran autosegmental, dan bukan lagi perubahan nilai fitur semata-mata seperti yang ditunjukkan oleh matriks fitur dalam model linear yang asal (Adi Yasran, 2005).

\section{C) PERUBAHAN/ut/ KEPADA [a $₫]$}

Ujaran informan menunjukkan kata yang berakhir dengan bunyi /ut/ akan direalisasikan sebagai [a $₫$ ] contohnya kata seperti /sambut/ dan /fabut/ akan diujarkan sebagai [sam.ba@] 'sambut' dan [ta.ba@] 'cabut'. Berdasarkan teori fonologi autosegmental, perubahan yang berlaku dapat diformalisasikan dalam rumus yang berikut: 
5. Geometri fitur menunjukkan $/ u / \rightarrow[a]$

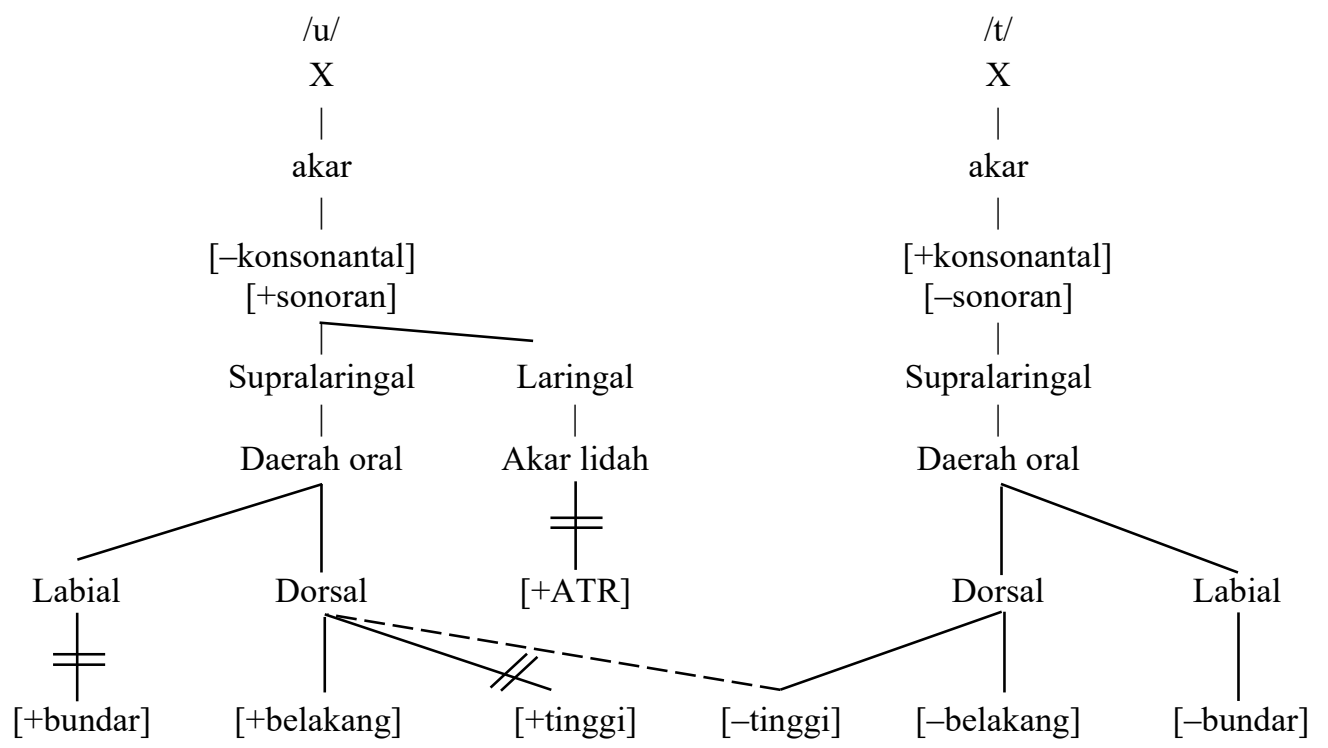

Berdasarkan rumus 5, proses nyah hubung fitur [+bundar], [+tinggi] dan [+ATR] daripada vokal /u/ akan menyebabkan representasi fonologi segmen vokal tidak lagi mempunyai ketiga-tiga fitur distingtif tersebut. Pada masa yang sama, proses asimilasi telah berlaku, iaitu apabila fitur [-tinggi] daripada konsonan /t/ yang bersebelahan dengannya disebarkan kepada segmen vokal lalu menyebabkan representasi vokal kini turut mempunyai fitur [-tinggi]. Berdasarkan rumus tersebut, maka kombinasi fitur [-bundar], [+belakang], [-tinggi] dan [-ATR] dalam representasi fitur vokal bersamaan dengan ciri distingtif bagi vokal rendah /a/ dalam sistem fonologi bahasa Kerinci.

Dalam hal ini, penyebaran fitur [-tinggi] daripada konsonan /t/ telah mempengaruhi perealisasian vokal /u/ yang berfitur [+tinggi] kepada vokal [a] yang berfitur [-tinggi]. Dengan kata lain, pengaruh fitur [-tinggi] daripada $/ \mathrm{t} /$ telah menjadikan segmen vokal kini turut bercirikan fitur [-tinggi]. Selain itu, rumus 5 mempunyai ciri kealamiahan yang bertujuan memudahkan artikulasi. Hal ini kerana vokal [a] dan konsonan /t/ di rima akhir kata kedua-duanya mempunyai persamaan dari segi fitur [-tinggi] dan [-bundar]. Berbeza dengan vokal /u/, ia berfitur [+tinggi] dan [+bundar] yang jelas menunjukkan perbezaan ciri distingtif dengan konsonan /t/ di koda kata yang berfitur [-tinggi] dan [-bundar]. Sejajar dengan prinsip ease of articulation, maka perubahan /u/ kepada [a] berlaku dalam bahasa Kerinci kerana bunyi *[ut] lebih mudah diujarkan.

Seterusnya, data turut menunjukkan perubahan terhadap konsonan /t/ di koda kata yang direalisasikan sebagai hentian glotis [@]. Dalam bahasa Kerinci, konsonan /t/ tidak dibenarkan menduduki posisi koda suku kata dan hal ini dikawal oleh kekangan syarat koda. Bagi mematuhi syarat tersebut, maka proses debukalisasi dilaksanakan. Melalui pelaksanaan proses debukalisasi seperti yang diformalisasikan dalam rumus 2, maka konsonan /t/ di koda kata dalam bunyi *[at] akan direalisasikan sebagai [@].

Menurut O'Brien (2010), gejala debukalisasi yang melibatkan konsonan /t/ dinamakan sebagai $t$ glottalization yang berlaku disebabkan kecenderungan penutur yang meminimumkan gerakan alat artikulasi ketika bertutur. Jika dibandingkan dengan konsonan hentian yang lain, O'Brien (2010) berpendapat tempoh penghasilan bunyi koronal lebih cepat diujarkan berbanding segmen bunyi dorsal atau labial. Hal ini sedikit sebanyak telah menyebabkan sebutan konsonan /t/ kurang jelas dan cenderung diujarkan sebagai hentian glotis [@] seperti yang dikemukakan dalam pendapat yang berikut, "The coronal gesture is generally faster than dorsal or labial gestures, so the duration of the closure could make [t] less distinct from a (mostly gestureless) glottal stop (pg. 242)'”. Di peringkat akhir pelaksanaan 
proses debukalisasi, output [a@] akan dihasilkan seperti yang direpresentasikan dalam kata [sam.ba@] 'sambut' dan [ta.ba@]] 'cabut'

\section{D) PERUBAHAN /uk/ KEPADA [0@]}

Ujaran informan Kerinci juga menunjukkan kata yang berakhir dengan bunyi /uk/ akan direalisasikan sebagai [o@] contohnya kata seperti /masuk/ dan /habuk/ akan diujarkan sebagai [mã.so dan [a.bo $]$ ] 'habuk'. Berdasarkan teori fonologi autosegmental, perubahan yang berlaku dapat diformalisasikan dalam rumus yang berikut:

6. Geometri fitur menunjukkan $/ u / \rightarrow[o]$

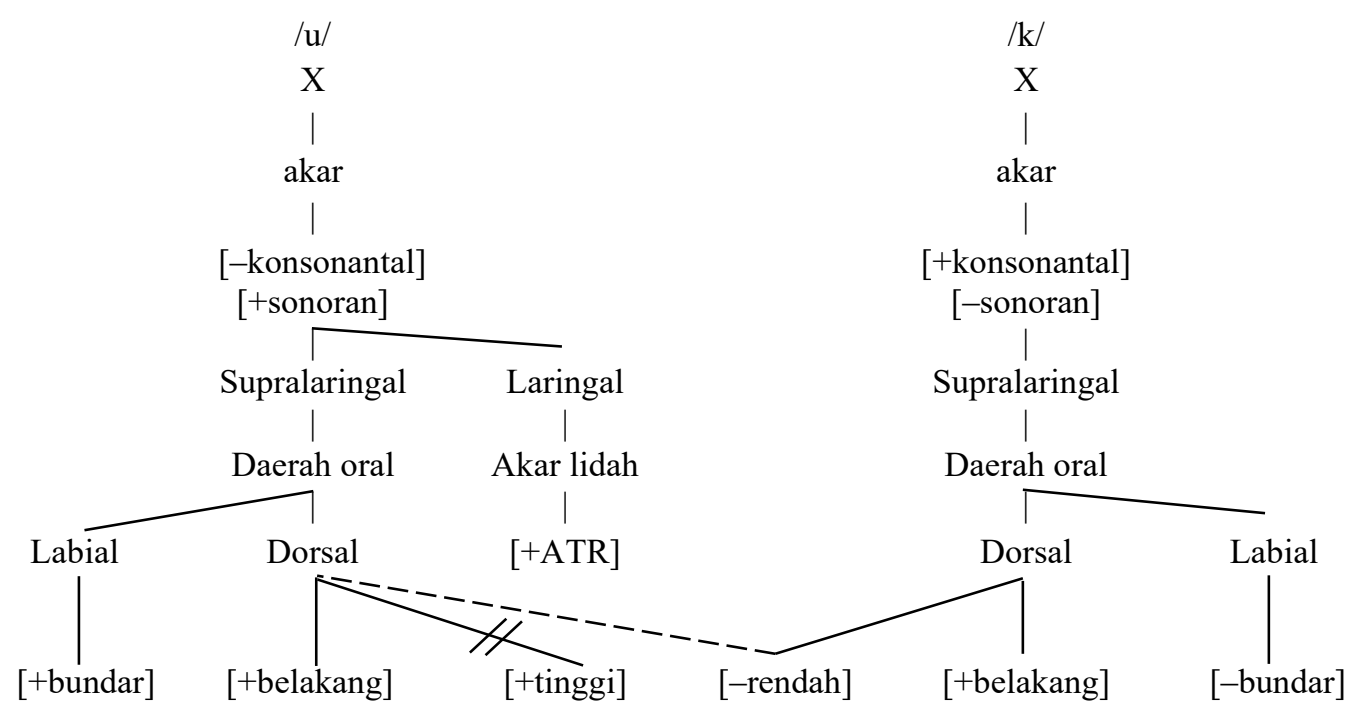

Berdasarkan rumus 6 , nyah hubung fitur [+tinggi] daripada vokal $/ \mathrm{u} /$ telah menyebabkan representasi fonologi segmen vokal kini tidak lagi mempunyai fitur [+tinggi]. Pada masa yang sama, proses asimilasi telah berlaku yang menunjukkan penyebaran fitur [-rendah] daripada konsonan / $\mathrm{k} /$ yang mengikutinya di akhir kata lalu menyebabkan representasi fonologi segmen vokal kini turut mempunyai fitur [-rendah]. Berdasarkan representasi segmen vokal dalam rumus 6, maka kombinasi fitur [+bundar], [+belakang], [+ATR] dan [-rendah] jelas bersamaan dengan ciri distingtif yang dimiliki oleh vokal [o] dalam bahasa Kerinci.

Berdasarkan rumus 6, penyebaran fitur [-rendah] daripada konsonan $/ \mathrm{k} /$ yang berada di akhir kata telah mempengaruhi perealisasian vokal /u/ kepada [o]. Perubahan yang berlaku menunjukkan asimilasi fitur kerana vokal [o] dan konsonan /k/ kedua-duanya berfitur [-rendah]. Dengan kata lain, output */ok/ yang dihasilkan lebih mudah diujarkan, iaitu berdasarkan perkongsian fitur distingtif yang sama di posisi rima akhir kata. Dalam analisis fonologi, perubahan /u/ kepada [o] mempunyai ciri kebolehramalan kerana rumus perendahan vokal seperti ini turut berlaku dalam kebanyakan bahasa lain seperti yang dijelaskan dalam kajian M. Yunus (1980) dan Teoh (1994).

Seterusnya, data sebelum ini menunjukkan konsonan $/ \mathrm{k} /$ di koda kata turut mengalami proses debukalisasi atau kehilangan fitur daerah akibat pelaksanaan nyah hubung fitur. Hal ini sejajar dengan kekangan syarat koda bahasa Kerinci yang tidak membenarkan konsonan hentian tak bersuara /p, t, k/ hadir di posisi koda. Melalui pelaksanaan proses debukalisasi seperti yang diformalisasikan dalam rumus 2, maka konsonan $/ \mathrm{k} /$ di koda kata dalam bunyi *[ok] akan berubah menjadi hentian glotis dan direalisasikan sebagai [@]. Malahan juga, perealisasian /k/ kepada [ $₫$ ] merupakan suatu fenomena fonologi yang alamiah kerana sering berlaku dalam kebanyakan bahasa di dunia. Di peringkat akhir 
pelaksanaan proses debukalisasi, output $[0 \Omega]$ akan dihasilkan seperti yang direpresentasikan dalam kata [mã.soø] 'masuk' dan [a.boø] 'habuk'.

\section{KESIMPULAN}

Berdasarkan perbincangan, hipotesis kajian tentang syarat koda bahasa Kerinci yang tidak membenarkan konsonan frikatif $/ \mathrm{s} /$ dan konsonan hentian tak bersuara $/ \mathrm{p}, \mathrm{t}, \mathrm{k} /$ menduduki posisi koda kata telah dapat dibuktikan, iaitu melalui pematuhan terhadap syarat koda bahasa Kerinci yang ditangani oleh proses debukalisasi yang merealisasikannya sebagai segmen frikatif glotis [h] dan segmen hentian glotis [@].

Pada masa yang sama, persoalan mengapa dan bagaimana vokal dalam bunyi /as/, /up/, /ut/ dan

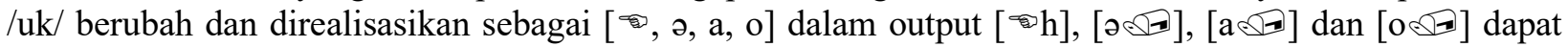
dijelaskan dari segi proses nyah hubung fitur yang dimiliki oleh setiap segmen vokal, dan proses asimilasi, iaitu melalui penyebaran fitur daripada segmen konsonan yang hadir bersebelahan dengannya dalam kata. Berdasarkan proses asimilasi yang berlaku, segmen vokal yang kehilangan titik artikulasi melalui proses nyah hubung sebelum ini akan memperoleh titik artikulasi baharu daripada segmen konsonan yang mengikutinya di akhir kata

Malah, fenomena fonologi yang berlaku juga menunjukkan bahawa proses asimilasi yang terlaksana terhadap bunyi vokal /as/, /up/, /ut/ dan /uk/ yang direalisasikan sebagai [

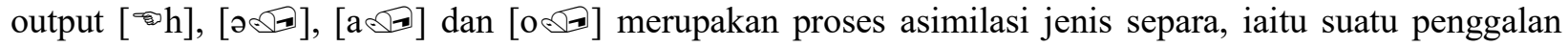
mengambil sebahagian fitur daripada segmen yang bersebelahan dengannya tanpa menggugurkan semua fitur asalnya, lalu menyebabkannya berkongsi fitur dengan segmen tersebut (Noor Azureen \& Sharifah Raihan, 2017). Dengan kata lain, perubahan yang berlaku didorong oleh syarat vokal dan konsonan harus mempunyai fitur yang hampir sama bertujuan memudahkan artikulasi.

Malahan juga, analisis menunjukkan bahawa kehadiran segmen hentian glotis [ $₫]$ boleh diramal melalui proses debukalisasi. Menurut Adi Yasran (2005), segmen yang kehadirannya boleh diramal tidak termasuk dalam inventori fonem sesebuah bahasa. Oleh itu, penyenaraiannya ke dalam inventori fonem konsonan bahasa Kerinci dianggap tidak berpada dan perlu dikecualikan daripada senarai inventori fonem konsonan bahasa tersebut. Dengan kata lain, jika suatu segmen tidak bertaraf fonem, maka ia perlu dikemukakan dengan tanda kurung siku seperti [@] dan bukannya tanda kurung palang seperti */

Selain itu, dalam konteks perubahan bunyi /as/, /up/, /ut/ dan /uk/ kepada [], [ə@], [a dan [o pula, perbincangan tentangnya tidak dijelaskan berdasarkan model skeletal KV yang merupakan salah satu model analisis yang turut terdapat dalam gagasan teori fonologi autosegmental. Hal ini kerana proses fonologi yang berlaku tidak melibatkan perubahan terhadap struktur suku kata sebaliknya melibatkan proses asimilasi yang lebih relevan dijelaskan berdasarkan proses hubung, nyah hubung, penyebaran fitur dan analisis berdasarkan model geometri fitur.

Kajian ini diharap dapat memberi pengetahuan dan penjelasan yang berpada tentang perubahan fonologi yang berlaku dalam sistem bunyi bahasa Kerinci, khususnya perubahan yang berlaku di rima akhir kata. Selain itu, diharapkan juga supaya kajian ini dapat memberi panduan tentang aplikasi teori fonologi autosegmental kepada ahli-ahli linguistik yang lain, dan membolehkan pengkaji mengaplikasi teori ini dalam analisis bunyi bahasa-bahasa lain.

\section{RUJUKAN}

Adelaar, K. A. (1992). Proto-Malayic: The Reconstruction of its Phonology an Parts of itsMorphology and Lexicon. Canberra: Pacific Linguistic. Series C No.119.

Adi Yasran Abdul Aziz. (2005). Aspek Fonologi Dialek Kelantan: Satu Analisis Teori Optimaliti. Tesis Doktor Falsafah. Bangi: Universiti Kebangsaan Malaysia.

Adi Yasran Abdul Aziz. (2012). Analisis Koda berdasarkan Kekangan dalam Dialek Kelantan.GEMA Online ${ }^{\text {TM }}$ Journal of Language Studies. 12(4), 1127-1145. 
Adi Yasran Abdul Aziz, Raja Masittah Raja Ariffin, Mohd Sharifudin Yusop \& Nur Farahkhanna Mohd Rusli (2014). Pengglotisan Geseran /s/ dalam Bahasa Kerinci. GEMA Online ${ }^{\circledR}$ Journal of Language Studies. 14(3), 225-242.

Amir Hakim Usman. (1983). Pengkajian Bahasa Kerinci. Jurnal Dewan Bahasa. 30(10), 181-187.

Amir Hakim Usman. (1988). Fonologi dan Morfologi Bahasa Kerinci Dialek Sungai Penuh. Disertasi Doktor Ilmu Sastra. Jakarta: Universitas Indonesia.

Asmah Haji Omar. (2005). Alam dan Penyebaran Bahasa Melayu. Kuala Lumpur:Dewan Bahasa dan Pustaka.

Asmah Haji Omar, Mohaini Mohd Saffar, Aminah Awang Basar, Salmah Jabbar, Raja Masittah Raja Ariffin, ... Zaiton Ismail (2013). Bahasa Minangkabau Mukim Sesapan Batu Minangkabau.Kuala Lumpur: Dewan Bahasa dan Pustaka.

Browman, C \& Goldstein, L. (1986). Towards an Articulatory Phonology. Phonology Yearbook 3. 219-252.

Clements, G. N. \& Hume, E. V. (1995). The Internal Organization of Speech Sounds. in. Goldsmith, J. A. The Handbook of Phonological Theory. Cambridge: Blackwell.

Corella Anak Stephen, Chemaline Anak Osup \& Siti Saniah Abu Bakar. (2017). Faktor Campur Kod dalam Kalangan Masyarakat Iban di Sarawak. PENDETA Journal Of Malay Language, Education and Literature, Jilid 8, 108-115.

de Lacy, P. (2002). The Formal Expression of Markedness. Doctoral Dissertation. Amherst: University of Massachusetts. Muat Turun 16 Februari 2017 daripada http://roa.rutgers.edu/files/5420902/542-09021-0.PDF.

Ernanda. (2011). On the Loss of the Phrasal Alternation in the Pondok Tinggi Dialect of Kerinci: A Stochastic Optimality Theory Approach. Tesis Sarjana. Nijmegen University.

Ernanda. (2015). Phrasal Alternation in the Pondok Tinggi Dialect of Kerinci an Intergenerational Analysis. Wacana. 16(2), 355-382.

Farid M. Onn. (1984). Konsep-Konsep Dasar Teori Fonologi Generatif. Seminar Linguistik Transformasi-Generatif, 3-5 Ogos 1984, Kuala Lumpur.

Goldsmith, J. A. (1976). Autosegmental Phonology. Cambridge: Massachusetts Institute of Technology.

Goldsmith, J. A. (1990). Autosegmental and Metrical Phonology. Oxford, United Kingdom: Basil Blackwell.

Halle, M. (1992). Phonological Features. Bright, W. (ed.). International Encyclopaedia ofLinguistics. Vol.3. New York: Oxford University Press.

Halle, M. (1995). Feature Geometry \& Feature Spreading. Linguistic Inquiry. 26. 146. Harishon Radzi, Fazal Mohamed Mohamed Sultan, Nor Hashimah Jalaluddin dan Zaharani Ahmad (2012). Analisis Bahasa Komunikasi Bangsa Minoriti Negrito Menerusi Pengimbuhan dan Peminjaman Kata. GEMA Online ${ }^{T M}$ Journal of Language Studies. 12(3), Special Section. 885-901.

Ito , J. (1986). Syllable Theory in Prosodic Phonology. Doctoral Dissertation. Amherst: University of Massachusetts.

Jakub Isman. (1958). Kerinci Phonology. Bloomington: Indiana University.

Jones, D. (1972). An Outline of English Phonetics. New York: Cambridge University Press.

Kenstowicz, M \& Kisseberth, C. (1979). Generative Phonology. New York: Academic Press.

Kozok, Uli. (2012). Manuskrip Melayu Abad ke-14 dari Kerinci. Jurnal Terjemahan Alam \& Tamadun Melayu (2). 85-104

Lombardi, L. (2001). Why Place and Voice are Different: Constraint - Specific Alternation in Optimality Theory.

Lombardi, L. (ed.) in Segmental Phonology in Optimality Theory. Constraints and Representation. New York: Cambridge University Press.

M. Yunus Maris. (1980). The Malay Sound System. Kuala Lumpur: Penerbit Fajar Bakti.

McKinnon, T. A. (2011). The Morphology and Morphosyntax of Kerinci Word Shape Alternations. Doctoral Dissertation. University of Delaware.

Mohd. Isa Farhy Yassin. (1971). Sistim Bunyi Loghat Kerinci dan Perbandingannya dengan Bahasa Melayu Standard. Majalah Dewan Bahasa. XIII(3). 162-169.

Mohd. Majid Konting. (1990). Kedah Penyelidikan Pendidikan. Kuala Lumpur: Dewan Bahasa dan Pustaka.

Nandra. (1999). Diftongisasi dalam Bahasa Minangkabau Umum. Puitika: Jurnal Humaniora. Edisi 7. 1-4.

Nelmawarni Bungo \& Nordin Hussin. (2011). Merantau ke Kuala Lumpur: Tradisi merantau dan Berdagang Masyarakat Minang. GEOGRAFIA TM Online Malaysian Journal of Society and Space 7 Special Issue: Social and Spatial Challenges of Malaysian Development. 116-131.

Nik Safiah Karim, Farid M. Onn, Hashim Musa \& Abdul Hamid Mahmood. (2010). Tatabahasa Dewan Edisi Ketiga. Kuala Lumpur: Dewan Bahasa dan Pustaka. 
Nor Hashimah Jalaluddin, Norlisafina Sanit, Zaharani Ahmad \& Harishon Mohd. Radzi. (2016). Variasi Kata Ganti Nama Dialek di Pesisir Sungai Perak: Analisis Geographical Information System (GIS). GEMA Online ${ }^{\circledR}$ Journal of Language Studies. 16(1), 109-123.

Nova Rina \& Fadlul Rahman. (2016). Analisis Absolute dan Oblique dalam Bahasa Kerinci Isolek Pulau Tengah. Jurnal Arbitrer. 3(2), 67-82.

Noor Azureen Hamid @ Ahmed \& Tajul Aripin Kassin. (2013). Analisis Fonologi Autosegmental dalam Proses Penyebaran Fitur Geluncuran Dialek MelayuSaribas. Jurnal Bahasa. Vol.13(2). 217-242.

Noor Azureen Hamid @ Ahmed \& Sharifah Raihan Syed Jaafar. (2017). Asimilasi Homorganik Nasal Dialek Melayu Saribas. GEMA Online ${ }^{\circledR}$ Journal of Language Studies. 17(2), 192218.

Nur Farahkhanna Mohd Rusli, Adi Yasran Abdul Aziz, Raja Masittah Raja Ariffin, Mohd Sharifudin Yusop \& Saidatul Faiqah Samasu. (2015). Derivasi Rumus Reduksi Vokal dan Pembentukan Glotis dalam Bahasa Kerinci. GEMA Online ${ }^{\circledR}$ Journal of Language Studies. 15(3), 83-97.

O’Brien, J. (2010). Perception and English t-glottalization. Ms., Santa Cruz: University of California.

O'Brien, J. (2012). An Experimental Approach to Debuccalisation \& Supplementary Gestures. Doctoral Dissertation. Santa Cruz: University of California.

Prentice, D. J \& Usman, A. H. (1978). Kerinci Sound-Changes and Phonotactics. Pacific Linguistics. Series $\quad C$ No.61. Canberra: The Australian National University.

Reijn, E. O. V. (2001). Sijaro Panta: A Folktale from Kumun, Kerinci: Text, Translation, Vocabulary, and Sketch of Kumun Phonology. Jakarta: Badan Penyelenggara Seri Nusa, Universitas Katolik Indonesia Atma Jaya.

Rifai, Y. (1954). Dialek Kerinci. Majalah Medan Bahasa. 4/3. 26-28. Jakarta: Kementerian P. P dan K. Roasharimah Ibrahim. (2009). Fonologi Bahasa Kerinchi: Satu Kajian di Kampung Kerinchi. Jabatan Linguistik, Akademi Pengajian Melayu, Universiti Malaya.

Roca, I. \& Johnson, W. (1999). A Course in Phonology. United State of America: Blackwell Publisher Inc.

Rohaidah Haron, Ab. Razak Ab. Karim \& Indirawati Zahid (2018). Pertembungan Bahasa di Selatan Thailand: Faktor dan Implikasi. PENDETA Journal of Malay Language, Education and Literature. Jilid 9, 117-129.

Rozaimah Rashidin \& Nor Diyana Saupi. (2011). Kata Ganti Nama dalam Dialek Kerinci. Jurnal Linguistik. 14. 116.

Sagey, E. C. (1986). The Representation of Features and Relations in Nonlinear Phonology. Doctoral Dissertation. United State of America: Department of Linguistics, Massachusetts Institute of Technology.

Schane, S. A. (1973). Generative Phonology. Englewood Cliffs: Prentice-Hall, Inc.

Shahidi A.H \& Rahim Aman (2011). An Acoustical Study of English Plosives in Word Initial Position produced by

Malays. 3L: Language Linguistics Literature ${ }^{\circledR}$, Southeast Asian Journal of English Language Studies. 17(2), 23 -33.

Teoh Boon Seong. (1994). The Sound System of Malay Revisited. Kuala Lumpur: Dewan Bahasa dan Pustaka.

Trask, R. L. (1996). A Dictionary of Phonetics and Phonology. London: Routledge.

Voorhoeve, P. (1970). Kerintji Documents. Bijdragen tot de Taal-, Land-en Volkenkunde 126. No. 4. 369-399.

Zaharani Ahmad. (2003). Harmoni Vokal dalam Bahasa Rungus dan Dusun Kimaragang: Suatu Analisis Fonologi Autosegmental. Dewan Bahasa. 3(4), 607-623.

Zaharani Ahmad. (2007). Proses Asimilasi dalam Bahasa Bisaya: Analisis Fonologi Autosegmental. Jurnal Bahasa. 7(1), 159-180.

Zaharani Ahmad \& Teoh Boon Seong. (2006). Fonologi Autosegmental: Penerapannya pada Bahasa Melayu. Kuala Lumpur: Dewan Bahasa dan Pustaka. 